\title{
DISTRIBUTION, MORPHOLOGICAL VARIATION AND NEW VARIETY OF BACCAUREA ANGULATA MERR.(PHYLLANTHACEAE)
}

\author{
Gunawan $^{1,2}$, Tatik Chikmawati ${ }^{3}$, Sobir $^{4} \&$ Sulistijorini $^{3}$ \\ ${ }^{1}$ Plant Biology Graduate Program, Department of Biology, Faculty of Mathematic and Natural Sciences, \\ Bogor Agricultural University, Bogor 16680 Indonesia \\ ${ }^{2}$ Department of Biology, Faculty of Mathematic and Natural Sciences, Lambung Mangkurat University, \\ Banjarbaru 70714 Indonesia \\ ${ }^{3}$ Department of Biology, Faculty of Mathematic and Natural Sciences, Bogor Agricultural University, Bogor \\ 16680 Indonesia \\ ${ }^{4}$ Department of Agronomy and Horticulture, Faculty of Agriculture, Bogor Agricultural University, \\ Bogor 16680 Indonesia \\ Email: gunawan@ulm.ac.id
}

Gunawan, Tatik Chikmawati, Sobir \& Sulistijorini. 2018. Distribusi, Variasi Morfologi dan Varietas Baru dari Baccaurea angulata Merr. (Phyllanthaceae). Floribunda 6(1): 1-11. - Baccaurea angulata (belimbing merah) adalah jenis endemik di Kalimantan yang dimanfaatkan sebagai bahan pangan dan obat tradisional, namun sejauh ini informasi distribusi dan variasinya masih sangat terbatas. Penelitian ini bertujuan memetakan lokasi-lokasi tumbuh pohon $B$. angulata, menggambarkan variasi morfologi, dan analisis fenetik $B$. angulata yang tumbuh di Kalimantan dan Pulau Natuna. Eksplorasi B. angulata dilakukan di Pulau Natuna dan empat provinsi di Kalimantan (Barat, Timur, Tengah dan Selatan). Peta persebaran dibuat dengan program ArcGIS versi 10.3. Pola distribusi dianalisis menggunakan indeks Morishita. Data morfologi batang, daun, bunga, dan buah digunakan untuk analisis fenetik belimbing merah berdasarkan koefisien Simple Matching (SM) dengan metode UPGMA. B. angulata tersebar secara acak di Kalimantan Barat, Tengah dan Pulau Natuna, tetapi memiliki pola penyebaran mengelompok di Kalimantan Selatan dan Timur. Penemuan B. angulata di desa Ceruk dan Limau Manis di Pulau Natuna dengan nama lokal belimbing besi merupakan rekaman baru. Peta sebaran B. angulata di Kalimantan dan Pulau Natuna disediakan. Secara morfologi, $B$. angulata di Kalimantan dan Pulau Natuna bervariasi pada beberapa ciri yaitu tepi stipula, permukaan tangkai daun, warna tangkai perbungaan betina, dan bentuk buah. Analisis fenetik mengelompokkan seluruh sampel ke dalam tiga kelompok $B$. angulata berdasarkan 20 ciri morfologi dengan nilai keserupaan 53\% sesuai dengan bentuk dan rasa buah. $B$. angulata dengan buah membulat diusulkan sebagai varietas baru dengan nama $B$. angulata Merr. var. globulus Gunawan.

Kata kunci: Baccaurea angulata, Kalimantan, Pulau Natuna, rekaman baru, varietas baru, Phyllanthaceae.

Gunawan, Tatik Chikmawati, Sobir \& Sulistijorini. 2018. Distribution, Morphological Variation and New Variety of Baccaurea angulata Merr. (Phyllanthaceae). Floribunda 6(1): 1-11. - Baccaurea angulata (belimbing merah) is an endemic species of Borneo. Fruits of Baccaurea angulata are usually utilized as food and local medicine, but up to now the information about its distribution and variation is very scarce. The objectives of the research were to map the distribution, describe the morphological variation, and analyze the phenetics of $B$. angulata in Natuna Island and Indonesian Borneo, Kalimantan. B. angulata was explored in Natuna Island and four Provinces of Kalimantan (West, East, Central, and South). The distribution was mapped using ArcGIS version 10.3. The distribution pattern was analyzed using the Morishita index. Morphological data of stem, leaves, flower and fruit were used to analyze the phenetics of $B$. angulata using Simple Matching coefficient, to construct a dendrogram using UPGMA method. $B$. angulata is randomly distributed in the West and Central of Kalimantan, also in Natuna, but it has a clumped pattern in South and East Kalimantan. The presence of $B$. angulata in the Ceruk and Limau Manis villages in Natuna Island with local name belimbing besi is a new record. $B$. angulata is morphologically variable in several characters, i.e. stipule margin, petiole surface, pistillate peduncle colour, and fruit shape. Phenetic analysis based on 20 characters grouped all individuals into three groups with similarity index of $53 \%$ according to the shape and fruit taste. The individuals of $B$. angulata with oval fruits are proposed to constitute a new variety, namely B. angulata Merr. var. globulus Gunawan.

Keywords: Baccaurea angulata, Kalimantan, Natuna Island, new record, new variety, Phyllanthaceae. 
Baccaurea angulata Merr. (belimbing merah; Phyllanthaceae) was first published by Merrill in 1929. This species has many different local names, for example: asam ketiak, pidau, umbing and umbung (Kalimantan, Borneo); embaling bobou, belimbing hutan (Brunei); embaling, belimbing uchong, pelawak, popotong, tampoi hutan, and liposu (Sabah); uchong, ujung, belimbing bukit, belimbing dayak, belimbing hutan, belimbing merah, tampoi belimbing (Sarawak) (Haegens 2000; Lim 2012).

$B$. angulata is considered to have less economic value when compared to its relatives such as rambai (B. motleyana). Fortunately, it is a species used as a food source and it has the potential to develop into a medicinal plant in the future. This plant produces a red fruit with star fruit-like shape. The edible part of this fruit is its pericarp and aril with sweet to acidic flavour. $B$. angulata is found in primary and secondary forests between $0-800 \mathrm{~m}$ asl (Haegens 2000). The increasing conversion of forest into palm oil and rubber plantations negatively affects the $B$. angulata populations by reducing its natural habitat.

Phytochemical analysis of the fruit peel of $B$. angulata has shown that it contains protein, carbohydrates, fibers, minerals and vitamin C (Voon \& Kueh 1999), vitamin A, E and anthocyanin compounds (Ahmed et al. 2014; Norazlanshah et al. 2015). Mikail et al. (2014; 2015) reported that $B$. angulata juice can be used to prevent athero-sclerosis, inhibit lipid peroxidase activity and induce antioxidant enzyme activity. $B$. angulata also has the potency to be a source of natural ingredients for cancer treatment (Adam \& Bahar 2015), an antioxidant (Ibrahim et al. 2013; Lim 2012), and to have anti microbial activity (Momand et al. 2014).

Previous studies (Haegens 2000; Uji 2004, 2007; Lim 2012) reported that the distribution of $B$. angulata is only in Borneo, where it is an endemic species. Up to now, no publication reported the presence of $B$. angulata outside Borneo. The information on morphological variation within this species is also very limited. Then, the information on the existence of a plant in a place and its variations is useful for data collection of plant populations, recording the diversity of flora and its habitat, also its development for further uses (Lestari 2014; Djuita et al. 2016). This study aimed to provide distribution information, and analysis the morphological variation within $B$. angulata.

\section{METHODS}

\section{Exploration of B. angulata}

The exploration and sample collection of $B$. angulata was carried out in Indonesian Borneo, Kalimantan and Natuna Island based on information from the forestry service and the local communities. The explored areas were 15 districts and cities in Kalimantan and Natuna Islands. The explored areas in West Kalimantan included Entikong, Ngabang, Sarumbi, Kembayan, Sompak, Sanggau, Nangapinoh, Sintang and Sambas. In East Kalimantan, Samarinda was explored. In Central Kalimantan, Muara Teweh and Pangkalan were visited. Marajai and Barabai were explored in South Kalimantan. In Natuna Islands Northeast Bunguran was sampled.

\section{Distribution Mapping, Morphological Character Observation and Data Analysis}

The distribution of $B$. angulata was mapped using ArcGIS version 10.3. based on the coordinates of the collecting point of the collections made during the exploration with GPS 60 Garmin, label information in 14 specimens of Herbarium Bogoriense (BO), 5 specimens of Herbarium Wanariset (WAN), and 20 specimens images from Herbarium Leiden (L). The distribution pattern was analyzed using Morishita index (Ip) (Morishita 1959). The values and patterns of species distribution are as follows: Ip $=0$; random distribution, which individuals spread in several places and cluster elsewhere. Ip > 0; clumped distribution, where individuals always be in groups and so rarely to be separated. Ip < 0 ; uniform distribution, which individuals are located in a specific place within the community (Michael 1994).

A total of $98 \mathrm{~B}$. angulata trees were observed for their morphological characters, which included qualitative and quantitative traits of stems, leaves, flowers and fruits (Table 1). The botanical terms used are based on Harris \& Harris (2006) and Rifai \& Puryadi (2008). The character measurements are arranged in a data matrix and used for phenetic analysis based on Simple Matching (SM) coefficient and Unweighted PairGroup Method Arithmetic Average (UPGMA) method. All analyzes were performed using NTSys ver 2.11a program (Rohlf 2004). 
Table 1. Characters and traits used in the phenetic analysis of B. angulata

\begin{tabular}{|c|c|c|c|}
\hline \multirow{2}{*}{$\frac{\text { No }}{1}$} & \multirow{2}{*}{$\begin{array}{l}\text { Characters } \\
\text { Crown shape }\end{array}$} & \multicolumn{2}{|c|}{ Traits (score) } \\
\hline & & $0=$ conical & $1=$ pyramidal \\
\hline & & $2=$ rounded & \\
\hline \multirow[t]{2}{*}{2} & Crown width (m) & $0=1.58-2.5$ & $1=2.5-3.25$ \\
\hline & & $2=3.25-4.5$ & \\
\hline \multirow[t]{2}{*}{3} & Bark colour & $0=$ bright brown & $1=$ greyish green \\
\hline & & $2=$ greyish brown & $3=$ dark brown \\
\hline \multirow[t]{2}{*}{4} & Stem diameter $(\mathrm{cm})$ & $0=0.23-0.43$ & $1=0.43-0.61$ \\
\hline & & $2=0.61-0.74$ & \\
\hline 5 & Texture of bark & $0=$ smooth & $1=$ rough \\
\hline 6 & Petiole surface & $0=$ glabrous & $1=$ sparsely hairy \\
\hline \multirow[t]{2}{*}{7} & Petiole length $(\mathrm{cm})$ & $0=3.5-5.5$ & $1=5.6-10$ \\
\hline & & $2=>10$ & \\
\hline \multirow[t]{2}{*}{8} & Leaf length $(\mathrm{cm})$ & $0=7.2-10$ & $1=10-20$ \\
\hline & & $2=20-30$ & $4=>30$ \\
\hline \multirow[t]{2}{*}{9} & Leaf width $(\mathrm{cm})$ & $0=3.1-5$ & $1=5-10$ \\
\hline & & $2=>10$ & \\
\hline \multirow[t]{2}{*}{10} & Leaf shape & $0=$ ovate & $1=$ elliptic \\
\hline & & $2=$ obovate & \\
\hline \multirow[t]{2}{*}{11} & Leaf apex & $0=$ acuminate & $1=$ acute \\
\hline & & $2=$ round & \\
\hline \multirow[t]{2}{*}{12} & Leaf base & $0=$ acuminate & $1=$ acute \\
\hline & & $2=$ round & \\
\hline 13 & Indumentum of leaf venation & $0=$ glabrous & $1=$ sparsely hairy \\
\hline 14 & Number of secondary vein & $0=<10$ & $1=>10$ \\
\hline \multirow[t]{2}{*}{15} & Stipule length (mm) & $0=3-5$ & $1=5-10$ \\
\hline & & $2=>10$ & \\
\hline 16 & Leaf length and width ratio & $0=2-3$ & $1=3.01-4.11$ \\
\hline 17 & Stipule margin indumentum & $0=$ glabrous & $1=$ hairy \\
\hline 18 & Outer surface of stipule & $0=$ glabrous & $1=$ sparsely hairy \\
\hline 19 & Fruit shape & $\begin{array}{l}0=\text { =pentagonal to hexagonal } \\
\text {-shaped in cross section }\end{array}$ & $\begin{array}{l}1=\text { round-shaped in cross } \\
\text { section }\end{array}$ \\
\hline 20 & Colour of inflorescence peduncle & $0=$ red & $1=$ green \\
\hline
\end{tabular}

\section{RESULTS AND DISCUSSION}

\section{Distribution of $B$. angulata in Indonesian Borneo and Natuna Island}

Based on data collected from specimens at Herbarium Bogoriense, Herbarium Wanariset and as well as exploration sites, B. angulata is distributed through out Kalimantan. B. angulata also distributed in Malaysia and Brunei (Haegens 2000). Some of the specimens collected before the year of 2000, which show some locations of $B$. angulata plants, have under gone changes, especially in the East Kalimantan location, Tanah Merah subdistrict. This is due to the alteration of forest area into oil palm and rubber plantations. Environmental damage, such as landfires that often occur in Kalimantan also influence to the distribution of $B$. angulata plants, can decrease the totally of trees. Ouinsavi \& Sokpon (2010) mentioned that climate change and environmental 
degradation can affect vegetation form and species distribution.

During the exploration of $B$. angulata, 98 trees were found. Sixty seven individuals were collected from primary and secondary forests, 5 individuals in a house yard, 23 individuals in the forest-edge and 3 individuals in the roadside. Local people utilize the fruit and harvest it directly from the forest and sell in the markets as fresh fruit. Based on the information from the local community, until now there no effort has been made to propagate $B$. angulata, although they know that it has economic benefits. Previous studies have reported that the distribution of $B$. angulata is only in Borneo. However, based on our exploration, B.angulata is also found in Ceruk village and Limau Manis village, North East Bunguran Subdistrict, Natuna Island, which is a new record.
In Natuna Island, B. angulata grows in secondary forest. Compared to trees from Kaliman$\tan$, B. angulata from Natuna Island has shorter trees and the leaf blades are narrower and smaller. These differences are likely due to the ecological and environmental differences in which they grows. Based on exploration, the average air humidity and the temperature of $B$. angulata locations in Natuna Island are $86 \%$ and $22-33.3^{\circ} \mathrm{C}$, respectively, which are higher compared to that of the $B$. angulata place in Indonesian Borneo with an average air humidity of $80 \%$ and temperature $23-$ $32{ }^{\circ} \mathrm{C}$. In addition, the average soil $\mathrm{pH}$ in Natuna Island is 6 which is lower than that of Indonesian Borneo, 6.3. The distribution of the $B$. angulata in Kalimantan is presented in Figure 1, and the distribution of the $B$. angulata $\mathrm{n}$ Natuna Island is presented in Figure 2.

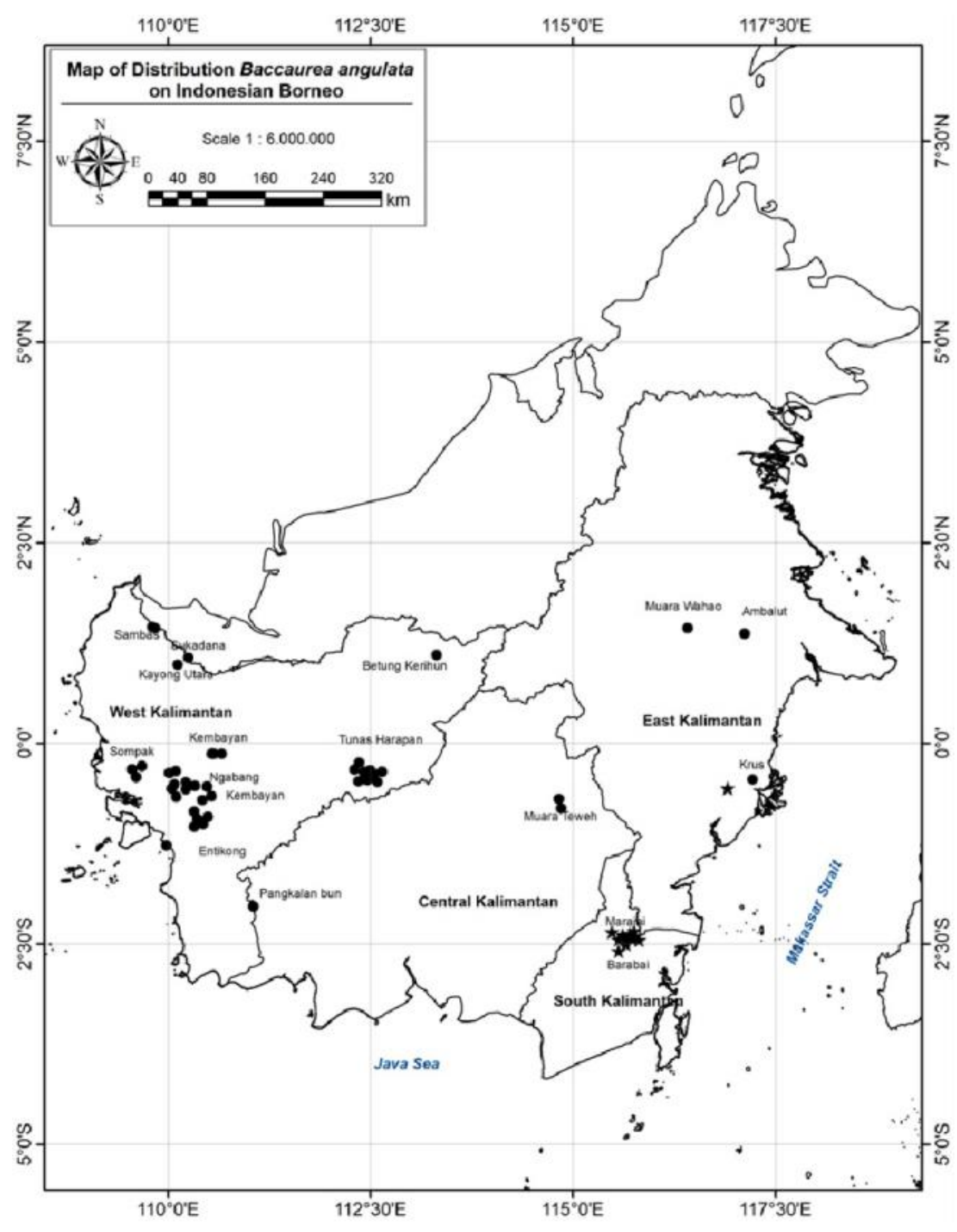

Figure 1. Distribution of $B$. angulata in Indonesian Borneo, Kalimantan. •: obovoid and pentagonal to hexagonal-shaped fruits, $\star$ : obovoid and round-shaped fruits. 


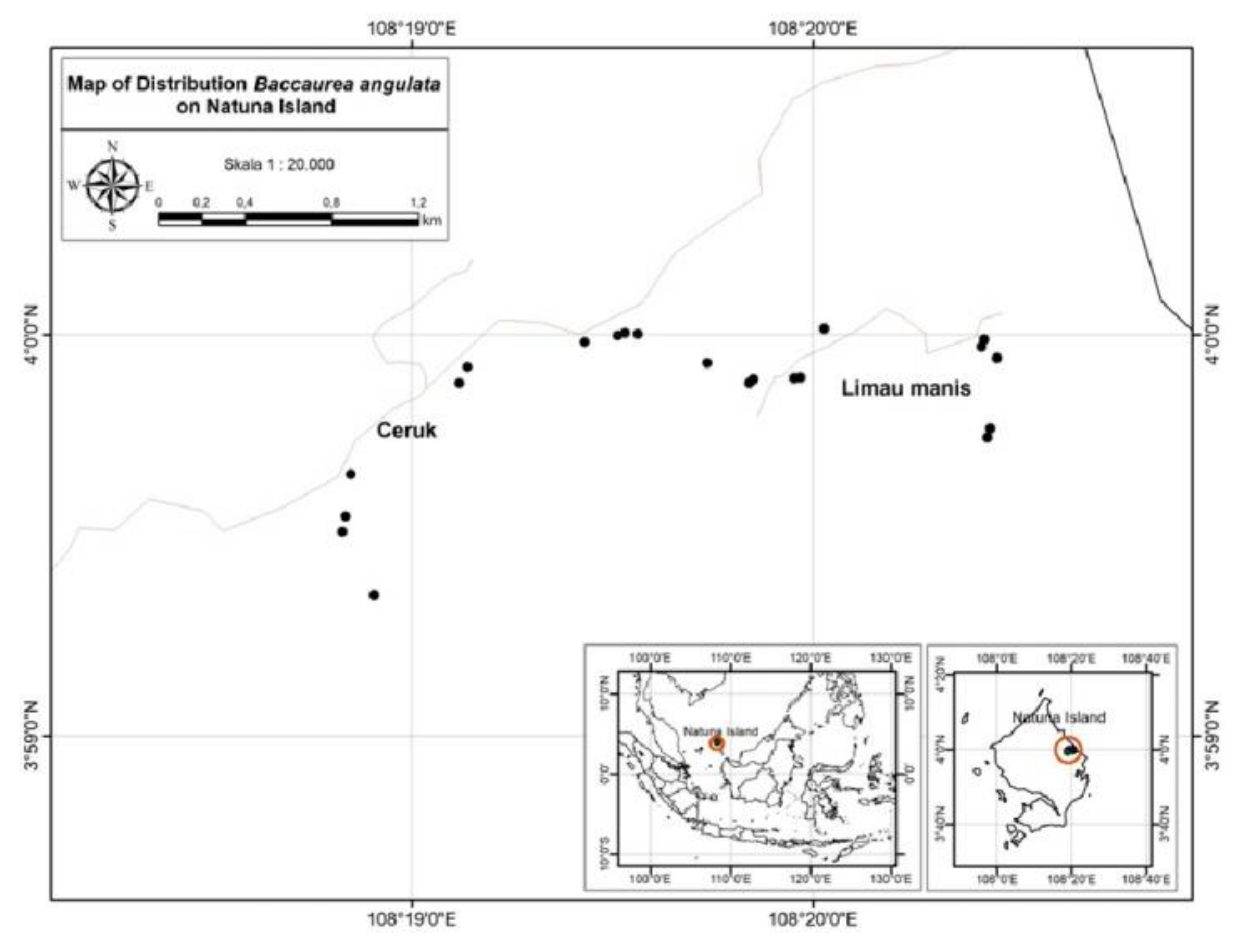

Figure 2. Distribution of B. angulata in Natuna Island.

The local distribution of $B$. angulata shows variation distribution patterns (Table 2). Most specimens are spread randomly in West Kalimantan, East Kalimantan, Central Kalimantan and in Natuna Island. However, in South Kalimantan a clumped pattern is found. This results is in agreement with Barbour et al. (1987) which stated that the pattern of distribution of seed plants tends to be clumped, because their seeds tend to fall near the parental tree. Based on observation, the pattern of random distribution that was found in several locations in the region of Kalimantan is caused by decreasing the natural habitat of $B$. angulata. Then, the decreasing of natural habitat can be caused by conversion of forest into oil palm and rubber plantation. In the other case, the pattern of distribution can also be influenced by the microclimate of the location where $B$. angulata grows.

Table 2. Distribution pattern of B. angulata in Kalimantan and Natuna Island

\begin{tabular}{llcc}
\hline Province & Locations & Distribution Index & Distribution Pattern \\
\hline West Kalimantan & Entikong & 0.0000 & Random \\
& Ngabang & 0.0012 & Clumped \\
& Sarumbi & 0.0063 & Clumped \\
& Kembayan & 0.0000 & Random \\
& Sompak & 0.0062 & Clumped \\
& Sanggau & 0.0000 & Random \\
& Nangapinoh & 0.0000 & Random \\
& Sintang & 0.0000 & Random \\
East Kalimantan & Sambas & 0.0000 & Random \\
Central Kalimantan & Samarinda & 0.0024 & Clumped \\
& Muara Teweh & 0.0000 & Random \\
South Kalimantan & Pangkalanbun & 0.0000 & Random \\
& Marajai & 0.00032 & Clumped \\
Riau & Barabai & 0.00006 & Clumped \\
\hline
\end{tabular}




\section{Morphological Variation of $B$. angulata}

$B$. angulata varied on some morphological characters such as the stipule margin, petiole surface, colour of the inflorescence peduncle, and the fruit shape. The stipule margin is ciliate or glabrous (Figure 3 ). The petiole surface is glabrous or minutely hairy (Figure 4). The colour of the pistillate inflorescence peduncle is red or green (Figure 5). The fruit is either obovoid with a round shape or pentagonal to hexagonal (Figure 6).

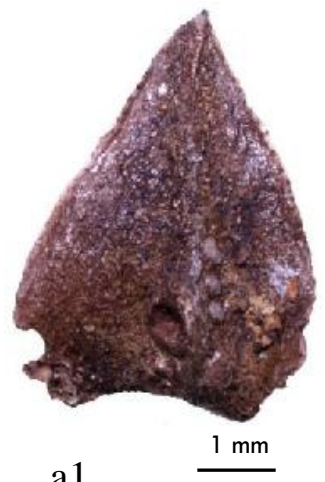

a1

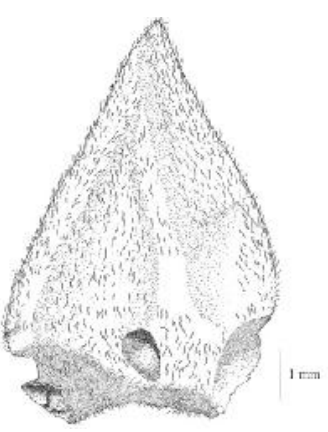

a2

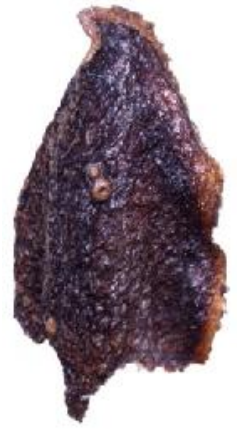

b1 $\quad \underline{\mathrm{mm}}$

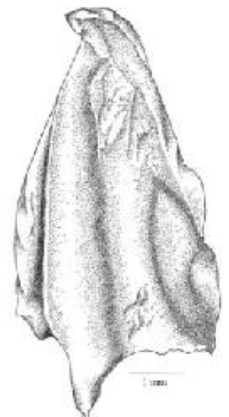

b2

Figure 3. Variation of the stipule margin, a1 \& a2: ciliate margin, b1 \& b2: glabrous margin. 1: photo, 2: drawing.
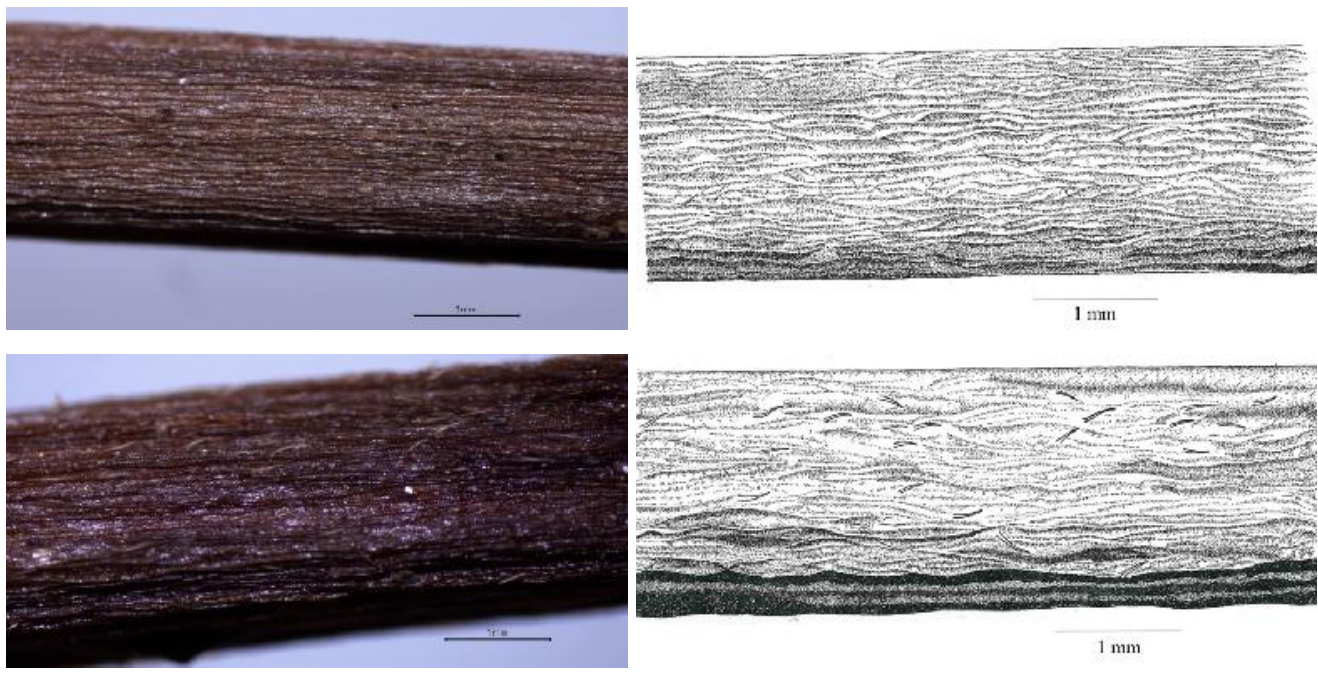

Figure 4. Variation of the petiole surface, a1 \& a2: glabrous, b1 \& b2: sparsely hairy. 1: photo, 2: drawing
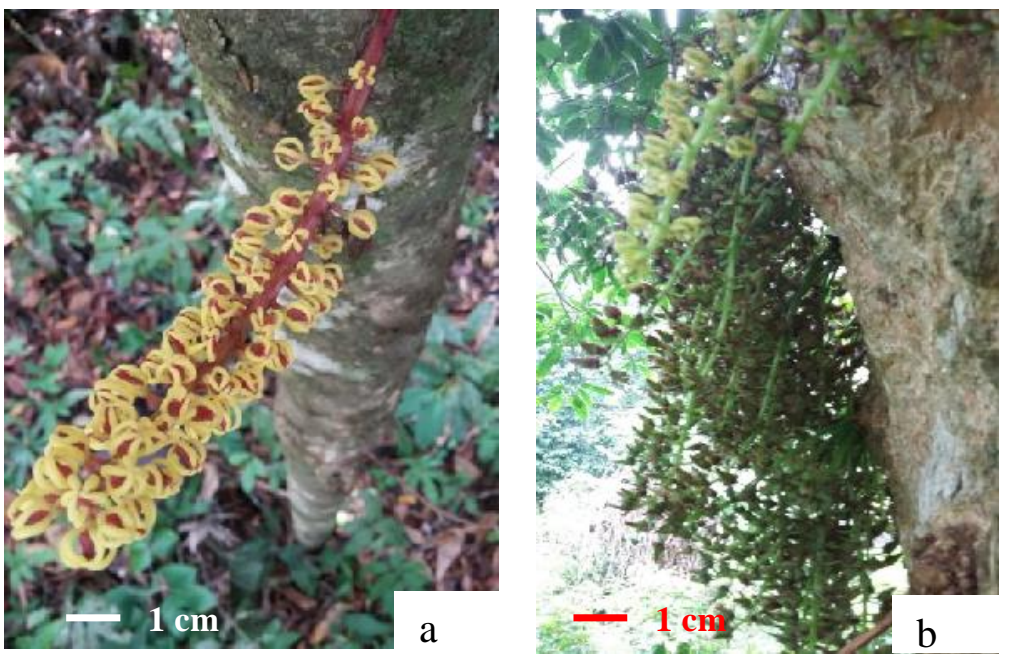

Figure 5. Variation in the colour of the pistillate inflorescence peduncle, a: red, b: green. 

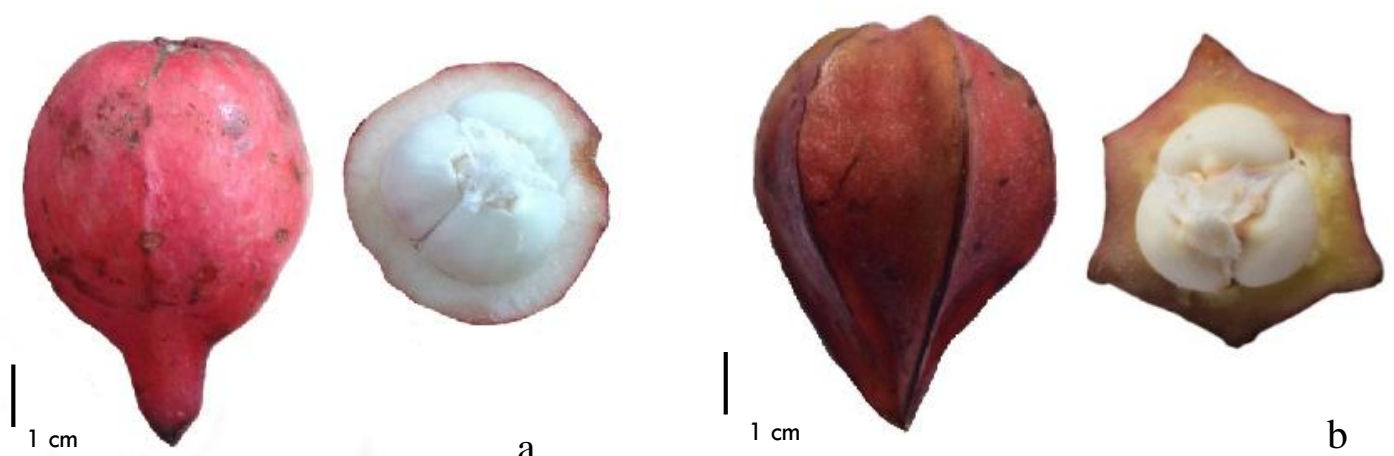

Figure 6. Variation in fruit shape, a: obovoid and round-shaped cross section of fruit with an acuminate tip; b: obovoid and hexagonal-shaped cross section of fruit with an acute tip.

Fruit length is $3.5-6.7 \mathrm{~cm}$, diameter $2.8-4.5$ $\mathrm{cm}$. Seeds are 1.56-1.9 $\mathrm{cm}$ long, and width 1.1$1.23 \mathrm{~cm}$. The different fruit shapes do not affect shape and size of the seeds. The fruits that are round in transverse section and that have an acuminate tip are not included in the species description of B. angulata by Merrill (1929) and Haegens (2000). This shape is mainly concentrated in South Kalimantan (Fig. 1) in group I in the dendrogram (Fig. 7) and regarded here to constitute a new variety under the name $B$. angulata Merr. var. globulus.

The fruits of $B$. angulata in Natuna Island have the same colour and star shape as $B$. angulata from Indonesian Borneo, but they are smaller. The characteristics of $B$. angulata in Natuna Island: Trees, is $8-11.5 \mathrm{~m}$ tall, $12-16.5 \mathrm{~cm}$ in diam, bark dark brown; densely hairy outside and ciliate along margin; petiole $3.5-6.5 \mathrm{~cm}$ long, glabrous; leaf blade oblong to ovoid, $12.3-26.5$ by $4.4-6.5 \mathrm{~cm}$, completely glabrous, upper surface shiny dark green lower surface pale green; inflorescenses 5$13.6 \mathrm{~cm}$ long, green, $34-50$ flowered, pedicels 1.45 $-2 \mathrm{~mm}$ long, densely hairy; flowers $1.04-2.1 \mathrm{~mm}$ in diam, sepals 4 or 5 , obovate, densely hairy; angled fruits, $3.5-4.8$ by $2.8-4 \mathrm{~cm}$, red; $1-3$ seeded, seeds $1.1-1.3$ by $0.8-1.1 \mathrm{~cm}$; wide; aril white.

\section{Phenetic Analysis of $B$. angulata}

The cluster analysis of 98 individuals was on 20 morphological characters. The resulting dendrogram showed three major groups (Figure 7).

In similarity coefficient of 53\%, all individuals were divided into three major groups. Group I consists of 12 individuals collected in South Kalimantan: Marajai (MRJ1, MRJ2, MRJ3, MRJ4, MRJ5, MRJ6, MRJ7, MRJ8, MRJ9, MRJ10,
MRJ11, MRJ12). Group I is grouped based on similarity of 7 characters: bark bright brown-coloured, crown slightly rounded, stipula with outside minutely-hairy, petiole minutely hairy, midrib minutely hairy below, peduncle of pistillate inflorescence red and fruit round-shaped in cross section. This group comprises the new variety.

Group II consists of eight individuals South Kalimantan: Barabai (BRB); West Kalimantan: Entikong (ENT2) and Sintang (SI7); Central Kalimantan: Muara Teweh (MTW1), and Natuna Island (NTA2, NTA3, NTA13, NTA17). All individuals in group II have similarity in 7 characters: of bark grayish-brown, crown conical, stipule glabrous, petiole glabrous, midrib glabrous, peduncle of pistillate inflorescence green and fruit pentagonal to hexagonal-shaped in cross section.

Group III consists of 77 individuals of $B$. angulata originating from West Kalimantan: Entikong (ENT1, ENT6, ENT3, ENT4, ENT5) Sarumbi (SAR1, SAR2, SAR3, SAR4), Ngabang (NGA1 to NGA21), Kembayan (KMB), Sintang (SIN1 through SIN17), Sanggau (SAG), Nangapinoh (NGP1, NGP2); East Kalimantan: Samarinda (SMR1, SMR2, SMR3); Central Kalimantan: Pangkalan Bun (PKB), Muara Teweh (MTW2); Natuna (NTA1, NTA4, NTA8, NTA6, NTA7, NTA8, NTA9, NTA10, NTA11, NTA18, NTA19, NTA20, NTA21, NTA22, NTA23, NTA24, NTA25). Group III is characterized: bark dark brown, crown pyramidal, stipule hairy, petiole glabrous, midrib glabrous, peduncle of pistillate inflorescence green and fruit pentagonal to hexagonal-shaped in cross section.

The morphological similarities of each group is not related to the origin of each individual. Spe-cimens from South Kalimantan (Marajai) are only scattered into group I, except individuals from 
Barabai. Then, other specimens from West Kalimantan (Entikong, Sarumbi, Ngabang, Kembayan, Kapuas Sintang, Sanggau, Nangapinoh, and Samarinda), East Kalimantan (Samarinda), and Central
Kalimantan (Muara Teweh and Pangkalanbun) are distributed into group II and III. Specimens from Natuna Island, also spread into groups II and III.

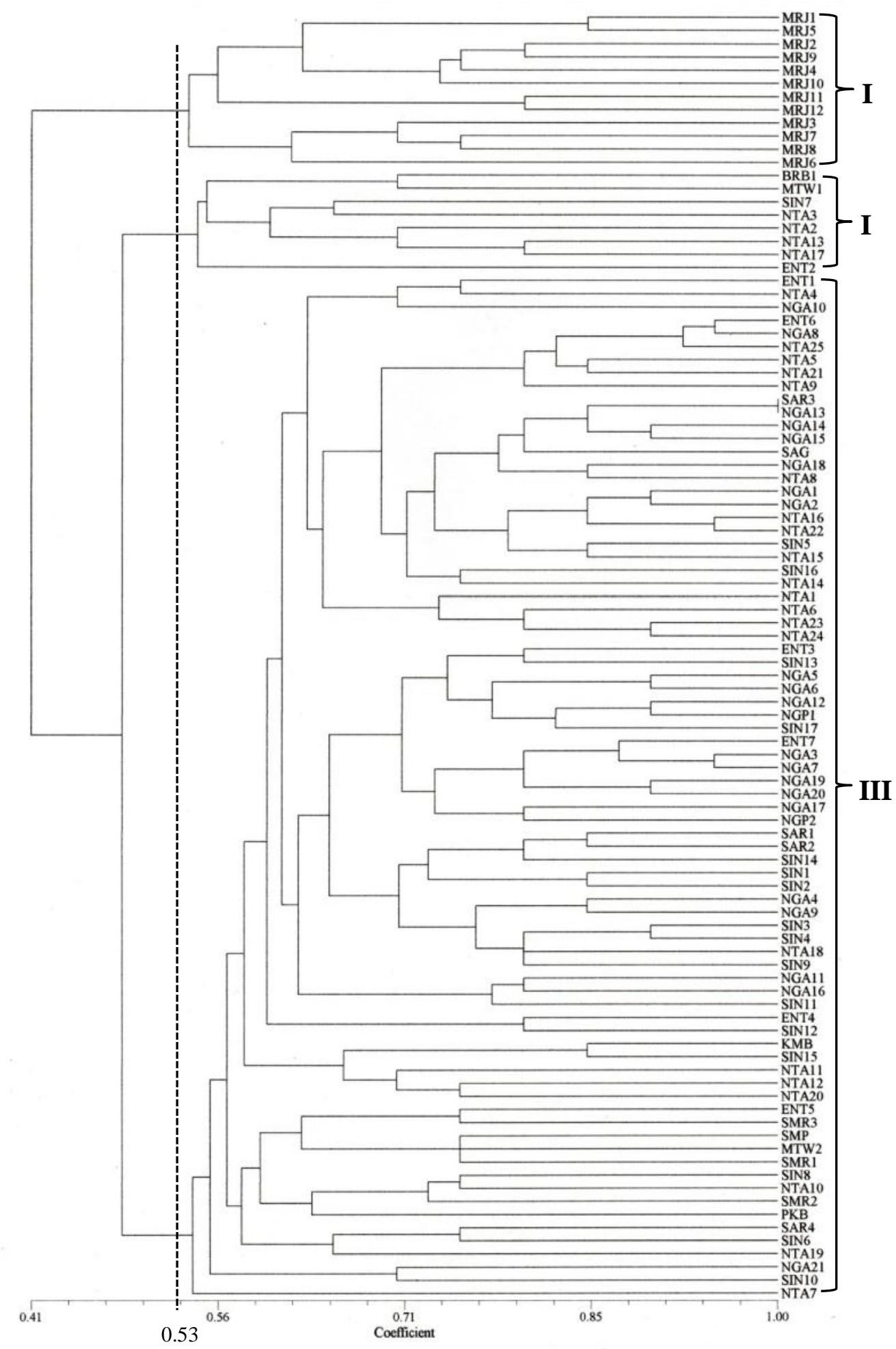

Figure 7. Dendrogram of $B$. angulata grouping based on 20 morphological characters using simple matching coefficient and UPGMA method. ENT. Entikong, NGA. Ngabang, SAR. Sarumbi, KMB. Kembayan, SMP. Sompak, SAG. Sanggau, NGP. Nangapinoh, SIN. Sintang, SBS. Sambas, SMR. Samarinda, MTW. Muara Teweh, PKB. Pangkalan Bun, MRJ. Marajai, BRB. Barabai, NTA. Natuna. 


\section{Taxonomic Treatment}

\section{B. angulata Merr.}

B. angulata Merr., Univ. Calif. Publ. Bot. 15 (1929) 148; Meyer, Bot. News Bull. Forest Dept., Sabah 7 (1967) 35; Airy Shaw, Kew Bull, Addit. Ser. 4 (1975) 46; Haegens, Blumea (2000) 12. Type: Elmer 2/542 (holo A; iso B, DS, G, L, U), Borneo, Sabah, Tawau.

Tree 5.5-22 $\mathrm{m}$ high, $9.6-40 \mathrm{~cm}$ in diameter; branchlets glabrous; young shoots pale straw when fresh. Terminal branching pattern weakly developed. Buttresses absent. Bark soft to hard, flaky, bright brown, grey-brown to red-brown to green, 9.6-40 cm in diameter; inner bark yellow to reddish to green, $0.6-4 \mathrm{~mm}$ thick. Stipules glabrous to densely hairy outside, glabrous inside, margin ciliate, $4.2-11 \mathrm{~mm}$. Leaves simple, alternate; blade elliptic to obovate, $12-40 \mathrm{~cm}$, length/ width ratio 2.2-3.6:1; base cuneate to attenuate (rounded); margin entire; apex acuminate to cuspidate to rarely obtuse; upper surface glabrous, dull to glossy dark green when fresh; lower surface glabrous, sometimes subglabrous at midrib; secondary veins 9-16 per side, closed at margin; venation reticulate, not distinct; petiole $2-12.5 \mathrm{~mm}$ long, cylindrical, glabrous. Staminate inflorescences cauline, green, $0.5-26 \mathrm{~cm}$ long, flowers distributed along inflorescence up to 51 flower, sparsely hairy, 3 flowers per node. Staminate flowers yellow, 2-2.8 $\mathrm{mm}$ in diam., pedicel 2-4 $\mathrm{mm}$ long, sepals 4 or 5 , obovate $1-1.5 \mathrm{~mm}$ long, apex slightly recurved, outside and inside densely hairy; stamens 6, 0.5-0.7 mm long, glabrous; anthers 0.5 -0.6 by $0.1-0.3 \mathrm{~mm}$, pistillode c. $0.4 \mathrm{~mm}$ high, densely hairy, hollow. Pistillate inflorescences, green to red, solitary or up to 7 clustered together, $3.8-26 \mathrm{~cm}$ long, subglabrous to densely hairy. Pistillate flowers $4-9 \mathrm{~mm}$ in diam., sepals 5 or 6 , elliptic, 8-9 $\mathrm{mm}$ long, outside and inside densely hairy; ovary urn-shaped, 3-5 mm long, 3-locular, densely hairy, wings $0-6$; style absent; stigmas 0.6 $-1.4 \mathrm{~mm}$ long, glabrous to subglabrous above, glabrous to densely hairy below. Fruits obovoid, round to star-shaped in transverse section, 1-3seeded, $3.5-6.7 \mathrm{~cm}$ fruit long, $2.8-4.5 \mathrm{~cm}$ in diam., base acute-acuminate, red to purple to pink to redbrown, petiole 4-8 $\mathrm{mm}$ long, pericarp 1-2 $\mathrm{mm}$ thick. Seeds globose to ellipsoid, laterally flattened, $1.56-1.9$ by $1.1-1.23 \mathrm{~cm}$, testa bright brown. Arillode white, $2.1-4.23 \mathrm{~mm}$ thick; sweet to sweetsour in flavour.

\section{Identification key to the varieties}

1. a. Leaf blades c. 2.2 times longer than wide. Pistillate inflorescence peduncle green to red. Fruit starshaped in transverse section, apex acute. var. angulata

b. Leaf blades 2.7-3.6 times longer than wide. Pistillate inflorescence peduncle red. Fruit round in transverse section, apex acuminate. .var. globulus

\section{a. var. angulata}

Bark grey-brown to red-brown to green when fresh; crown conical to pyramidal. Petiole glabrous; stipules glabrous to densely hairy outside; leaf blades $12-39$ by $4-13.6 \mathrm{~cm}, 2.2$ times longer than wide; sometimes subglabrous at midrib. Peduncle of pistillate inflorescence green to red; fruits obovoid, star-shaped in cross section; apex acute.

Specimens examined. Indonesia, Borneo, West Kalimantan, Kayong Utara, 23 Maret 2010, Hery Yanto, Endri Setiawan, Adi Bejo, Edi 1906001 (BO); Indonesia, Borneo, West Kalimantan, Betung Karihun National Park, 23 Februari 2000, Sidiyasa K 1368339 (BO); Indonesia, Borneo, West Kalimantan, Ngabang, 23 Februari 2017, Gunawan 012; Indonesia, Borneo, East Kalimantan, Manubar, 16 Juli 1951, A. Kostermans 1476896 (BO); Indonesia, Borneo, East Kalimantan, Kayu Mahakam, 16 km from Ambalut, 18 July
1976, K. Kartawinata 1894543 (BO); Indonesia, Borneo, East Kalimantan, Kayu Mahakam, 16 km from Ambalut, 18 July 1976, K. Kartawinata 1894544 (BO); Indonesia, Borneo, East Kalimantan, Samarinda-Kurs, Kebun Raya Unmul, 11 Mei 2017, Gunawan 050; Indonesia, Borneo, Center Kalimantan, Muara Teweh, 20 Juni 2017, Gunawan 063-064; Indonesia, Natuna, Limau Manis; 26 Mei 2017, Gunawan 066-070; Indonesia, Natuna, Ceruk 28 Mei 2017, Gunawan 071-076.

Distribution: Borneo; Natuna

Habitat and Ecology: Primary and secondary rain forest, altitude $40-800 \mathrm{~m}$ asl

b. var. globulus Gunawan, var. nov.- Fig. 8 . - Type: Indonesia, Borneo, Kalimantan Timur, Tanah Merah, Lempake, 10 Km from Samarinda, 6 Januari 1977, K. Kartawinata 1441 (BO).

Bark bright brown; crown slightly rounded; stipula with outside minutely hairy, petiole minute- 


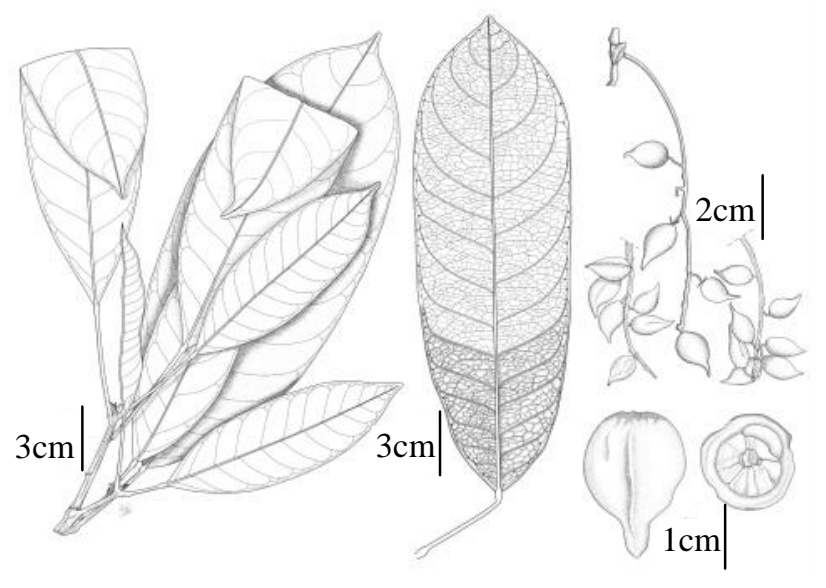

Fig. 8. B. angulata Merr. var. globulus Gunawan, var. nov. (K. Kartawinata 1441, Gunawan 082).

ly hairy, midrib minutely hairy below, leaf blades $22.5-40$ by $8.5-11 \mathrm{~cm}, 2.7-3.6$ times longer than wide; peduncle of pistillate inflorescence red; fruit obovoid, round-shaped in transverse section; apex acuminate.

Ecology and habitat: primary forest, altitude 144-675 $\mathrm{m}$ asl.

Distribution: East and South Kalimantan.

Local name: si lulung.

Utilization: fruit eaten, fruit peel also used as vegetables.

Specimens examined. Indonesia, Borneo, West Kalimantan, Tanah Merah, Lempake, $10 \mathrm{Km}$ from Samarinda, 6 January 1977, K. Kartawinata 1441 (BO); Borneo, East Kalimantan, Kutai Timur, Muara Wahau, PT. Narkata Rimba, 13 December 2009, Arifin Z \& Suharja I, 0926349 (WAN); Borneo, South Kalimantan, Balangan, Marajai, 6 June 2016, Gunawan 082.

Local people commonly harvest fruits of $B$. angulata from the forest (Siregar 2005). In West Kalimantan, fruits of $B$. angulata are sold as fresh fruit or processed as a spice (sour-spicy spice) (Subekti et al. 2005). In Central Kalimantan, local people use the fruit as a fermented beverage. In South Kalimantan and Natuna Island, fruits of $B$. angulata are found in many traditional markets during the fruit season. In addition, the stem can be used as building materials and furniture (Lim 2012). In general, B. angulata blooms from July to September (Haegens 2000), and October to November will be in fruiting season. Based on observations, at the time of exploration and description of the local poeple, the flowering season of $B$. angulata almost coincide with durian.

\section{CONCLUSION}

B. angulata was found to be distributed not only in Kalimantan but also in Natuna Island, with the local name belimbing besi, which has the same characteristics as $B$. angulata that grows in Kalimantan. The morphological variations of $B$. angulata consisted of stipule margin, petiole surface, the color of pistillate inflorescence peduncle, and the shape of the fruit. Variants with round-shaped in transverse section and apex acuminate are proposed to be a new variety named $B$. angulata var. globulus. It have been found only in East and South Kalimantan. Based on the morphological characteristics, $B$. angulata trees were divided into 3 groups with similarity coefficient of 53\%. Group I consisted of $B$. angulata with rounded-shape and sweet flavor, group II is hexagonally-shaped fruit with sour flavor, and group III is group of $B$. angulata with hexagonally-shaped fruit and sweetsour flavor.

\section{ACKNOWLEDGEMENTS}

The authors would like to thank Ministry of Research, Technology, and Higher Education for providing BPPDN scholarship program which has funded this research. Head and staff of Herbarium Bogoriense (BO) and Wanariset Herbarium (WAN) are thankfully acknowledged for all the facilities provided.

\section{REFERENCES}

Adam M \& Bahar MS. 2015. Expression of Matrix Metalloproteinase-13 in Human Skin Melanoma Cancer Treated by Baccaurea angulata in vitro. Journal of Basic and Applied Research 1 (1): 21-28.

Ahmed IA, Mikail MA, Ibrahim M, Hazali N, Rasad MSBA, Gani RA, Wahab RA, Arief SJ \& Yahya MNA. 2014. Antioxidant actovity and phenolic profile of various morphological parts of underutilized Baccaurea angulata fruit. Food Chemistry.doi: http:// dx.doi.org/ 10.1016/j.foodchem.2014.09.122

Barbour MG, Burk JH \& Pitts WD. 1987. Terrestrial Plant Ecology (2nd ed.). CA: The Benjamin/Cummings Publishing Company, Inc.

Djuita NR, Hartana A, Chikmawati T \& Dorly. 
2016. Distribusi Kapulasan (Nephelium Ramboutan-Ake (Labill.) Leenh.) di Pulau Jawa dan Kekerabatan Morfologinya. Floribunda 5(4):129-164

Haegens R. 2000. Taxonomy, phylogeny, and biogeography of Baccaurea, Distichirhops, and Nothobaccaurea (Euphorbiaceae). Blumea Supplement 12.

Harris JG \& Harris MW. 2006. Plant Identification Terminology. An Illustration Glossary. Utah (US): Spring Like Publishing.

Ibrahim D, Hazali N, Jauhari N, Omar MN, Yahya MNA, Ahmed IA, Mikail MA \& Ibrahim M. 2013. Physicochemical and antioxidant characteristics of Baccaurea angulata fruit juice extract. African Journal of Biotechnology 12(34): 5333-5338.

Lestari R. 2014. Morphological Variation and Species Distribution of Baccaurea dulcis (Jack) Mull. Arg. in West Java, Indonesia. International Journal of Biology 6(1):17-28

Lim TK. 2012. Edible Medicine and Non-Medicine Plants: Volume 4. London New York. Springer.

Merrill ED. 1929. Plantae Elmerianae Borneenses. Univ. Calf. Bot. 15: 145-153.

Mikail MA, Ahmed IA, Ibrahim M, Hazali N, Rasad MSBA, Ghani RA, Wahab RA, Arief SJ, Isa MLM, Draman S, Ishola AA \& Yahya MNA. 2014. Changes in The Markers of Atherosclerosis Following Administration of Belimbing Dayak (Baccaurea angulata) Fruit Juice in Experimental Rabbits Fed With Cholesterol Diet. International Journal of Advances in Agricultural \& Environmental Engg (IJAAEE) Vol. 1. http://dx.doi.org/10. 15242/IJAAEE.C614516.

Mikail MA, Ahmed IA, Ibrahim M, Hazali N, Rasad MSBA, Ghani RA, Hashim R, Wahab RA, Arief SJ, Isa MLM, Draman S \& Yahya MNA. 2015. Baccaurea angulata fruit inhibits lipid peroxidation and induces the increase in antioxidant enzyme activities. $E \mathbf{E}$ ropean Journal Nutrition. DOI 10.1007/ s00394-015-0961-7.

Michael PE.1994. Metode Ekologi untuk Penyelidikan Ladang dan Laboratorium. Universitas Indonesia. Jakarta.

Momand L, Zakaria R, Ibrahim M, Mikail M, Jalal T \& Wahab A. 2014. Antimicrobial effect of
Baccaurea angulata fruits extracts against human pathogenic microorganisms. Medical \& Aromatic Plants V. 3(4):1-5. http:// dx.doi. org/10.4172/2167-0412.1000172.

Morishita M. 1959. Measuring of The Dispersion on Individuals and Analysis of the Distributional Patterns. Kyushu University. Japan

Norazlanshah, Afiq M, Muhammad \& Masri M. 2015. Determination of phytochemicals and vitamin content of under utilized Baccaurea angulata fruit. Journal Pharmacognosy and Phytochemsitry 4(4): 192-196.

Ouinsavi C \& Sokpon N. 2010. Morphological variation and ecological structure of Iroko (Milicia excelsa Welw CC Berg) population accross different biogeographical zones in Benin. International Journal of Forestry Research, 1, 1-11. http://dx.doi.org/10. 1155/ 2010/658396.

Rifai MA \& Puryadi D. 2008. Glosarium Biologi. Jakarta (ID). Pusat Bahasa Departemen Pendidikan Nasional.

Rohlf FJ. 2004. NTSyspc. Numerical Taxonomy and Multivariate Analysis System. User Guide. Department of Ecology and Evolution. State University of New York. New York [US]: Exeter Software.

Siregar M. 2005. Review: Species diversity of local fruit trees in Kalimantan: Problem of conservation and its development. Biodiversitas 7(1): 94-99.

Subekti A, Yeni S, Sumaryadi T, Anggraito B \& Ibrahim TM. 2005. Penggalian Data Pendukung Domestikasi dan Komersialisasi Jenis, Spesies, dan Varietas Tanaman Buah di Kalimantan Barat. Prosiding Lokakarya I Domestikasi \& Komersialisasi Tanaman Hortikultura. Puslitbang Hortikultura, Balitbang Pertanian, Departemen Pertanian. Jakarta. 23 -34 .

Uji T. 2004. Keanekaragaman Jenis, Plasma Nutfah, dan Potensi Buah-buahan Asli Kalimantan. BioSmart 6(2): 117-125.

Uji T. 2007. Review: Keanekaragaman Jenis BuahBuahan Asli Indonesia dan Potensinya. Biodiversitas 8(2): 157-167.

Voon BH \& Kueh HS. 1999. The nutritional value of indigenous fruits and vegetables in Sarawak. Asia Pacific Journal of Clinical $\mathrm{Nu}$ trition 8: 24-31. 